in the same room, even when they were a few yards away from the source of radiation.

We conclude from these observations that if ultraviolet lamps are used in experiments with biological material, care must be taken to distinguish the effects of the radiation per se from those of the ozone produced by it.

\section{E. WANGERMANN}

H. J. LACEY

Department of Botany, University College, Leicester.

1 Bull. Torrey But. Club, 60, 161 (1933).

\section{Identification of Tertiary Pollen Grains with those of New Guinea and New Caledonian Beeches}

SEVERAL years ago, when certain pollen grains from Tertiary deposits in south-eastern Victoria were referred to the genus Nothofagus ${ }^{1}$, it was recognized that some of them seemed to be intermediate in form between the two types of pollen grims that normally occur in this genus. At that time these divergent types were believed to be the pollen grains of extinct species of Nothofagus, and, as such, it seemed doubtful whether their exact affinity would ever be determined.

Examinations of the pollen grains of one of the New Guinea beeches, first discovered by Pulle in 1912 and independently recognized as Nothofagus by Brass and van Steenis in 1939, and of another beech discovered quite recently in New Caledonia by Dr. Baumann-Bodenheim, have shed light on the affinities of the fossil pollen. The pollen grains of both trees fall neither into the menziesii pollen group ( $N$. menziesii, N. cunninghami, N. moorei and N. obliqua) nor the fusca group (N.fusca, N. truncata, $N$. solandri, N. cliffortioides, N. gunnii and, according to Cranwell ${ }^{2}$, the bulk of the South American species) but are similar to the Tertiary pollen grains referred to by Cookson as $N$. sp. $e$.

This close agreement between the living and fossil pollen grains (Figs. 1-6) implying, as no- doubt it does, a close affinity between the parents of each, indicates a long past-history and a far wider geographical distribution than at present. $N$. sp. $e$., which is probably the commonest of the Australian Tertiary pollen types, has been observed, sometimes in large numbers, in deposits that range from southern Queensland to Tasmania and westward into South Australia. Similar, if not identical, 'intermediate' pollen species have been distinguished in Cretaceous and Tertiary beds in New Zealand ${ }^{3}$.

Several morphological and anatomical distinctions between the New Guinea beeches and other species of Nothofagus have already been observed by Langdon", who has remarked that "in certain respects they are sufficiently unlike the more typical members of that genus to justify their reference to a new section of the evergreen beeches". Their pollen morphology, so far as it is known at present, supports this statement.

Male flowers of the New Guinea species mentioned were collected by Mr. A. Schindler at Aiyura in the Eastern Highlands Division of New Guinea, and kindly forwarded to me by Mr. : J. S. Womersley, forest botanist, Department of Forests, New Guinea.
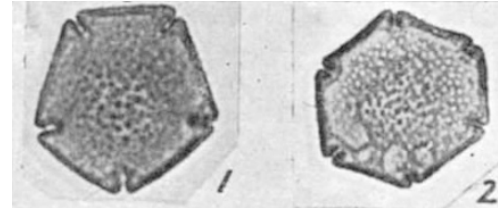

2
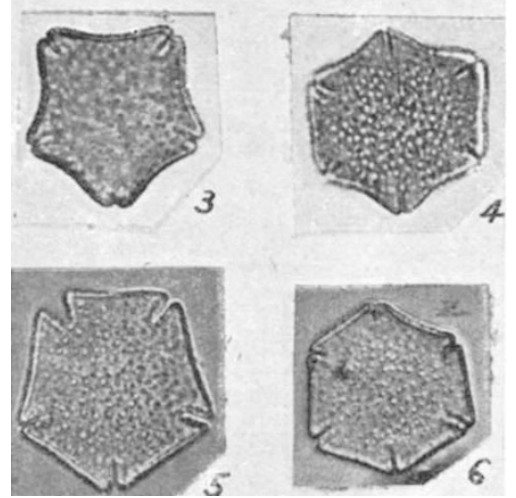

(1) and (2) Acetolysed pollen grains of Nothofagus from Aiyura,

New Guinea. $\times 600$
(3) and (4) Acetolysed pollen grains of Nothofagus from New

(5) and (6) Acetolysed pollen grains of $N$. sp. e. from Oligocene clay, Yallourn, Victoria. $\times 600$

Anthers of one of the New Caledonian species were generously supplied by Dr. M. G. BaumannBodenheim, of the Botanical Gardens, Zurich.

Department of Botany,

IsABEL C. COOKSON

University of Melbourne.

Jan. 22.

${ }^{1}$ Cookson, I. C., Proc. Linn. Soc. N.S.W., 71, 49 (1946).

${ }^{2}$ Cranwell, L., Rec. Auck. Inst. Mus., 2, 175 (1939).

${ }^{9}$ Couper, R. A., N.Z. Sci. Rev., 9, 5 (1951).

${ }^{4}$ Langdon, I. M., Bot. Gaz., 108, 350 (1946-47).

\section{Secondary Piliferous Layer in the Lupin}

THE communication by J. B. Goodey on a secondary piliferous layer in Hippeastrum ${ }^{1}$ leads me to record a similar structure in Lupinus.

During the examination of seedlings of Lupinus arboreus grown in the laboratory, a yellow gelatinous layer was noticed to appear on the roots simultaneously with the emergence of root hairs. This layer was found to consist of the disorganized cells of the epidermis and the two outer layers of cortex. Root hairs had originated in the third layer of cortical cells and penetrated the outer layers of smaller cells either directly or after some distortion. No root hairs were seen arising from epidermal cells.

In culture, seedlings were not infected by nematodes; but plants growing in the wild on the drier parts of sand dunes were highly susceptible to attack. Seedlings in this habitat all had exceptionally heavy developments of root hairs.

Dominion Museum,

P. A. Lush

Wellington, C.3,

New Zealand.

Dec. 11.

'Nature, 167, 822 (1951). 